\title{
GRABADOS DE GOYA SOBRE CIEGOS
}

\author{
BARBÓN GARCÍA JJ ${ }^{1}$
}

Francisco de Goya y Lucientes (FuendetodosZaragoza, 1746 - Burdeos, 1828) ha sido, junto a Picasso, el grabador más importante de la historia del arte español y sus estampas constituyen una parte fundamental de su obra. El pintor, influido por Rembrandt, se dedica al grabado de creación mostrándose como un gran innovador y un gran maestro del claroscuro. Hay que tener en cuenta que el grabado fue el único medio de reproducción masiva de imágenes hasta la aparición de la fotografía.

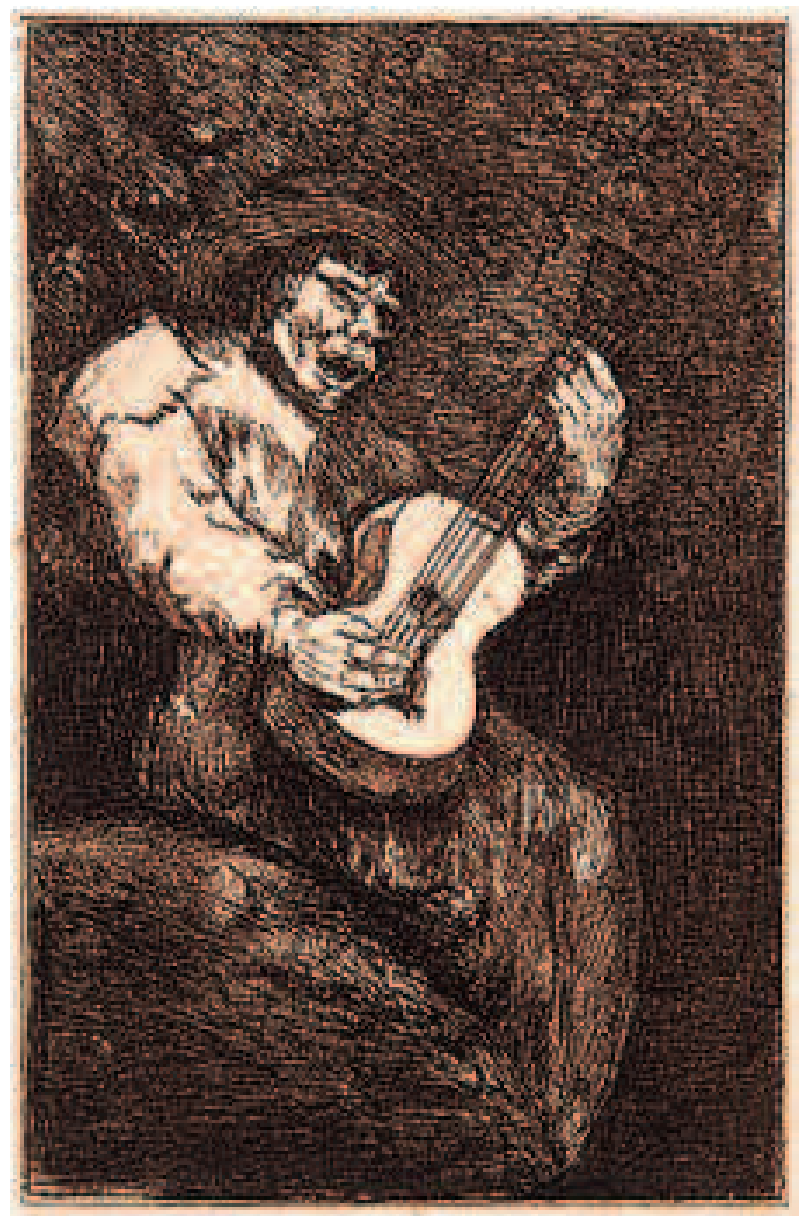

El cantor ciego.
La base del grabado consiste en el trazado de surcos sobre una plancha metálica mediante procedimientos mecánicos, como el buril y la punta seca, y con productos químicos como el aguafuerte y el aguatinta. El aguafuerte, método usual de los grabados de Goya, consiste en calcar el dibujo en una plancha barnizada mediante rayado; la plancha se sumerge en un ácido, el aguafuerte, que va modulando los surcos donde se deposita la tinta que se transmitirá al papel. El aguatinta, aplicado a la plancha grabada al aguafuerte, permite obtener diferentes tonalidades en las líneas utilizando capas de betún de Judea o resina. Finalmente, la plancha se puede retocar con trazos de buril para producir líneas más nítidas y oscuras o con la punta seca para obtener líneas más suaves e indefinidas.

Los grabados de Goya se pueden dividir por temas: Estampas religiosas, Las Copias de cuadros de Velázquez, La tauromaquia, Los desastres de la Guerra, Los caprichos y unas Estampas sueltas entre las que nos encontramos tres dedicadas a ciegos que nos muestran la evolución del grabado en Goya. El ciego de la guitarra (sobre 1778) representa una escena popular relacionada con uno de los

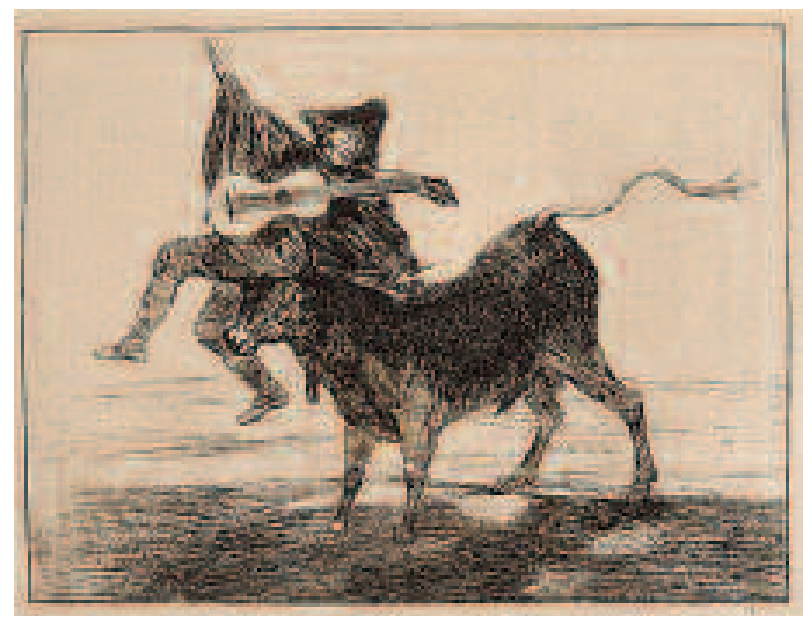

Dios se lo pague a usted.

\footnotetext{
1 Doctor en Medicina. Hospital San Agustín de Avilés. Oftalmología. Avilés (Asturias). España. E-mail: jjbarbon@telecable.es
} 


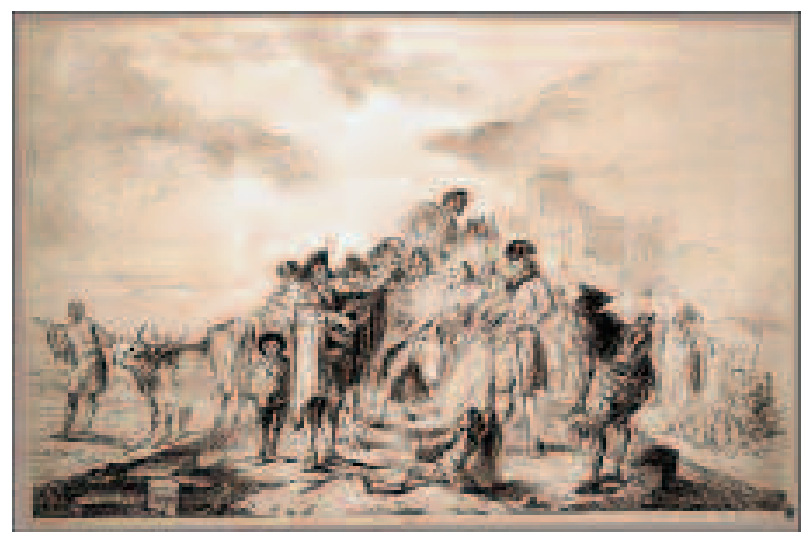

El ciego de la guitarra. cartones para tapices realizados en sus primeros años en la Corte. En los años anteriores a la Guerra de Independencia grabó Dios se lo pague a usted (1804), con la imagen de un ciego con su guitarra cogido por un toro y, por último, El cantor ciego (entre 1824-1828) pertenece a su etapa final de exilio en Burdeos.

\section{BIBLIOGRAFÍA}

1. Goya en la Biblioteca Nacional. www.bne.es/esp/bidigital.htm

2. Carrete J, Vega J. Goya, grabador. In: Cuadernos de arte español. Historia 16 (44): Madrid; 1991. 